\title{
Distribution Patterns and Factors Affecting the Selection of the Destination Country of Indonesian Migrant Workers of Lampung
}

\author{
Ari Darmastuti \\ International Relations Department \\ Lampung University \\ Lampung, Indonesia \\ ari.darmastuti@fisip.unila.ac.id
}

\author{
Astiwi Inayah \\ International Relations Department \\ Lampung University \\ Lampung, Indonesia \\ astiwi.inayah@fisip.unila.ac.id
}

\author{
Khairunnisa Simbolon \\ International Relations Department \\ Lampung University \\ Lampung, Indonesia \\ khairunnisa.simbolon@fisip.unila.ac.
}

\begin{abstract}
Lampung Province is one of the provinces in Indonesia that sends many workers abroad. The efforts to send workers abroad are part of international migration which is motivated by unfavorable conditions in the area of origin and better conditions which are considered favorable in the destination country. This study aimed to produce a study of the distribution pattern and factors that influence the selection of destination countries for Indonesian Migrant workers from Lampung. This study used a qualitative approach. This approach is intended as an analytical understanding process based on an empirical paradigm to investigate how the distribution patterns and factors influence the selection of migrant workers destination countries from Lampung in 2015-2020. The research results showed that the most popular destination countries among migrant workers from Lampung are Taiwan, followed by Hong Kong, Malaysia, Singapore, and Brunei Darussalam. The main factors that drove migrant workers to work abroad are limited access and employment opportunities in the country and higher salaries abroad. Socio-cultural factors that influenced the selection of destination countries for immigrant workers from Lampung are the similarity of language and culture that are still allied, the presence of friends or relatives who have previously worked abroad (chain migration), and the friendliness and respect of the local population towards migrant workers. Security factors that influenced the decision to select the destination country include social security and good health in the workplace, local government services that are fast and reliable, as well as ensuring security and order. Meanwhile, other factors that influenced the selection of the destination country are uncomplicated work requirements and migrant worker's interest in technological advances in the destination country.
\end{abstract}

Keywords: Indonesian migrant workers, distribution pattern, destination country

\section{INTRODUCTION}

Sending Indonesian migrant workers abroad is one solution to overcome the scarcity of job opportunities in the country and one of the efforts to overcome unemployment due to the limited availability of domestic jobs. The sending of labor is part of international migration which is motivated by various factors, both pull factors and push factors. An example is the unfavorable conditions in the area of origin that acted as a driving factor for migrating abroad. Meanwhile, better conditions that are considered favorable in the destination country of placement are an attraction for migrating abroad [1]. In general, migrant workers who work abroad are motivated by economic pressures.

The National Agency for the Placement and Protection of Indonesian Migrant Workers noted (Badan Nasional Penempatan dan Perlindungan Tenaga Kerja Indonesia or BNP2TKI) that the number of migrant workers stationed in various countries in 2018 reached 283,640 workers. Of this amount, $47 \%$ of workers work in the formal sector and 53\% work in the informal sector which is spread over 20 types of work. BNP2TKI also noted that there were 20 countries with the highest number of migrant workers. Of the 20 countries, Malaysia is the main destination country for migrant workers, reaching 90,671 workers or almost a third of the total migrant workers working abroad. While Hong Kong is in second place with the number of migrant workers reaching 73,917 workers, and Taiwan in third position with 72,373 workers. Meanwhile, China is only ranked 20th with a total migrant workers of 22 workers [2].

The number of migrant workers from Lampung has increased. BNP2TKI Lampung stated that during 
2019 the number of migrant workers from Lampung tended to increase from the number of migrant workers in 2018. The increase was still dominated by female workers (Tenaga Kerja Wanita or TKW) both from the formal sector or companies or informal or independent. Meanwhile, based on the number of regional origins, the highest number is still dominated by migrant workers from East Lampung Regency [3]. In contrast to national data which makes Malaysia and Hong Kong the main work targets, of the 21,472 migrant workers from Lampung spread across 20 countries in the world, most of the migrant workers work in Taiwan (10,309 people), Hong Kong $(4,129$ people), Malaysia (3,803 people), and Singapore. $(2,431$ people)

Data from BNP2TKI Lampung stated that based on the number of migrant workers by regional origin, gender, and sector in 2018 and 2019, an increase in 2019 was 584 people from the informal sector, which in 2018 was 12,226 people, so the total in 2019 was 12,810 people. While in the formal sector there was an increase of 654 people, which in 2018 was 6,627 people, so the number of migrant workers in the formal sector in 2019 was 7,281 people. Meanwhile, based on regional origin, the highest number was occupied by migrant workers from East Lampung Regency in 2019, a total of 7,504 people, with details of 4,525 people in the informal sector and 3,014 in the formal sector. While the second position is occupied by Central Lampung Regency with details of 2,090 people in the informal sector and 1,035 people in the formal sector. And the third position is occupied by South Lampung Regency with details of 1,020 people in the informal sector and 655 people in the formal sector. The number of TKW from Lampung as of December 2019 was 15,259 people, with details of 12,803 people working in the informal sector and 2,456 people working in the formal sector. While the number of TKW from Lampung as of December 2018 was 13,820 with details of 12,206 people working in the informal sector and 1,614 people in the formal sector [3].

The data shows that migrant workers is a crossborder employment phenomenon that has an important contribution not only to migrant workers from Lampung, but also to the economic conditions and welfare of the people in the migrant workers sending areas. Although this phenomenon socioeconomically has important implications for the people of Lampung, in-depth research on the distribution of destination areas and the reasons for the selection of destination countries by migrant workers from Lampung has not been widely carried out. A search of various scientific articles on this issue yielded the following findings. Sihombing, Yaakob, and Safarudin (2011) stated that employment opportunities and prospects for Indonesian migrant workers are still very open, both in terms of income generation opportunities for families at home and the opportunities that exist in accordance with Indonesian migrant worker's competitive advantage or those that can also be created by Indonesian migrant workers for filling the opportunities that exist abroad [4].

Other studies show the following. Loganathan, et.all (2019) emphasized their study on the protection of migrant workers from the aspect of access and availability of health insurance [5]. They stated that migrant workers are generally vulnerable in terms of access and availability of health insurance. In addition to these studies, Madrah and Suharko's study (2019) raised an interesting new theme about student migrant workers in Korea as cultural intermedieries (bridges or cultural liaisons) between countries of origin and destination countries in the fields of music, fashion, culinary, and others [6]. Sayono, Utami, Ayundasari (2018) examined socio-cultural factors that influence people's orientation to the status of migrant workers and the desire to become migrant workers [7]. Using the theory of push and pull factors, the researchers concluded that there are certain push and pull factors that cause changes in people's attitudes in South Malang to do or not to migrate to work abroad. Wright and Clibborn (2019) studied factors related to employment opportunities found that new migrant workers are the most vulnerable group compared to other groups of migrant workers in terms of wage vulnerability, employment protection, and other aspects of migrant workers [8]. Other research conducted by international scientists regarding migrant workers showed that there are significant differences between various groups of migrant workers in their working conditions and workplaces [9], [10]. This is still related to the status of new or old migrants with their workplace conditions, new workers generally find working conditions worse than old migrant workers.

\section{THEORETICAL FRAMEWORK}

The International Labor Organization (ILO) defines a "Migrant Worker" as a person who migrates, or has migrated from one country to another, with an image that the person will be employed by someone other than himself or herself, including anyone normally recognized as a migrant, to work [11]. This concept is closely related to the problem of international migration as an unavoidable phenomenon in an increasingly open world and globalization that occurs everywhere in the world. Therefore, it is necessary to study the concept of international migration as a concept that is closely related to migrant workers.

Migration is the movement of people across regional boundaries to other regional boundaries within a certain period of time [12]. Population migration can be permanent or non-permanent Migration can be divided into two types, namely internal migration and international migration. According to Lee (2000) international migration is a 
population movement activity that includes aspects of change of place of residence, the purpose of migrating as well as the desire to settle or not settle in the destination area [12]. International migration can be divided into two scopes, based on spatial and temporal aspects. International migration is the result of economic, social and political changes that then influence migration decisions. Migrants make decisions based on networks of personal relationships, existing experiences, and beliefs [13]. According to Everett S. Lee (2000) there are 4 factors that influence the flow of migration, namely factors in the area of origin, factors at the destination, barriers between, and individual factors [12]. Individual factors can be said to be the main factor in making the decision to move or not. Everet Lee (1966) stated that there are push and pull factors for a person to migrate between countries. Among the driving factors from the country of origin of migrant workers are the consideration of low salaries, limited employment opportunities and low social access of people in the country of origin. While the pull factors in the country of placement are competitive salaries, low unemployment and the tendency of someone to leave their home country [14].

Meanwhile, the Neoclassical Economy theory presented by Douglas S. Massey et al (1993) is both from a macro and micro approach [15]. This macro approach assumes that the main cause of migration is the difference in salaries between sending and receiving countries. That is, if there is no difference in salary receipts it will end the migration of workers and migrant workers will not migrate if the difference is not visible. In addition, international migration is also influenced by labor market mechanisms. This means that other markets such as insurance and capital markets do not have a very important effect on the flow of migrant workers. Furthermore, the international migration of workers can be controlled by the government through labor market regulations, both from sending and receiving countries. In response to the macro approach, then the micro approach also applies in this theory. Someone who decides to migrate has actually calculated the costs and benefits, which ultimately leads to the conclusion that migrating provides a net income and is greater than that in the migrant worker's home country. Migrant workers predict that net gains in future periods are derived from attention to pay and the possibility of doubling their work in the receiving country. In addition, policies between sending and receiving countries also greatly affect the size of labor migration [15].

Labor migration is usually defined as the movement of people across borders for the purpose of finding work in a foreign country through official or unofficial means, facilitated or not, labor makes an economic contribution to both the sending and the destination countries. The workforce helps to increase the size of the labor force in the destination country and can assist development in their own country through remittances of their income [16]. Another migration theory that is popular, especially in developing countries, is the chain migration theory. Basically, this theory explains the process of making a person's decision to leave his hometown which is associated with the presence of family or friends who are already in the destination country. Migrant workers chooses and determines to work abroad depending on several factors, both push and pull factors [17]. This study focused more on factors that exist in the destination country.

Mabogunje (1970) and Kritz\& Zlotnik (1992) stated that migration decision making is not only due to push and pull factors but also cultural factors, social systems, access to migration and psychological factors of migrating actors [18], [19]. This theory complements the theory of Everett S. Lee (2000) [12]. According to Mabogunje (1970) and Kritz\& Zlotnik (1992), psychological factors influence the decision making of individual migrants to migrate, so personal factors can be influenced by these psychological factors [18], [19]. Then the barrier or intermediate factors can be influenced by cultural factors and migration access. Psychological factors can be determined by the characteristics of migrant actors, namely age or education. Barrier factors can occur due to cultural differences that are quite far between the area of origin and destination, so that migration actors will prefer destination areas that have almost the same culture as their area of origin before finally migrating to areas that have cultural differences with the area of origin.

Likewise, poor migration access in destination areas makes migration actors choose destinations where migration access is easy to obtain [1].

The choice of destination countries is often very limited, determined by the needs of the job market in that country as well as by the market accessible to recruitment agencies. When the recruitment agency determines the country of destination, the migrant workers has little or no choice in the matter. The destination countries of Indonesian migrant workers are generally countries in Southeast Asia, East Asia, and the Middle East. Malaysia and Saudi Arabia are the two main destination countries. Many migrant workers choose Malaysia for reasons of geographical proximity to Indonesia, similar history, language and culture, and lower costs. Migrant workers who go to the Middle East, especially countries such as Saudi Arabia, Kuwait, the Arab Emirates, and Bahrain have reasons for the possibility of going on a pilgrimage. On the other hand, migrant workers are also interested in Hong Kong and Taiwan Province China because the salaries of domestic workers are also quite large. The relationship of migrant workers returning from these countries also affects migrant 
workers flows there. Migrant workers from the same area often go to the same country, as they are more likely to use the same recruitment agency or intermediary in the village, or personal contacts in the destination country [16].

\section{RESEARCH METHODS}

This qualitative research is designed to understand in depth the distribution pattern of destination countries and the factors that influence migrant workers from Lampung for choosing the destination country to work in. The objects of this research are 2 (two) namely: (1) migrant workers from Lampung who is working abroad or migrant workers who is currently at home, but there is still a desire to work abroad again; (2) other relevant resource persons, especially from institutions, both government and non-government, which are related to migrant workers affairs.

Primary data were obtained from two sources, namely: (1) documents from government agencies and other institutions containing information about the pattern of migrant workers distribution in various countries; (2) the results of interviews with selected resource persons. Secondary data is obtained from other sources, including data from the mass media, statements quoted from various pages, and so on.

The main data collection uses in-depth interviews, documentation, and literature studies. First, the indepth interview technique is open and in a structured form. This technique is used to obtain various information according to the needs of the research objectives. Second, the documentation technique is intended to obtain a large number of facts and data stored in materials in the form of documents. Most of the available data is in the form of reports, news events, and clippings. Third, the literature study technique used to collect data related to research. These data can be obtained from various sources such as books, journals, and the internet (online).

The data that have been collected are as follows: (1) interviews with 12 migrant workers who are currently working and have worked in Taiwan, Hong Kong, Korea, Malaysia, and Singapore; (2) two focussed group discussions (FGD) with the leader and staff of the Lampung Provincial Government Manpower Office and the leader and staff of the Indonesian Migrant workers Protection Agency (Badan Perlindungan Pekerja Migran Indonesia or BP2MI); (3) documents from reports from the Lampung Provincial Government Manpower Office and from BP2MI. Interviews with 12 migrant workers who are working abroad were conducted online via Whatsapp conversations while FGDs with agency offices were conducted in each office.

Data analysis was carried out before entering or going into the field, while in the field, and after finishing in the field [20], [21]. Stated that "The analysis has been carried out since formulating and explaining the problem, before going into the field and continuing until the writing of research results". In this study, data analysis will be more focused during the process in the field along with data collection, processing, and after being in the field. The stages of data analysis followed the process of data reduction, data presentation, conclusion drawing, and verification.

\section{RESULTS AND DISCUSSION}

\section{A. The Reason Why Migrant Workers from Lampung Chose the Destination Country}

Based on the records of the focused group discussions (FGD) of the research team with the Department of Manpower and BP2MI of Lampung Province, migrant workers from Lampung identified the following countries as migration destinations, namely: Afghanistan, Albania, Algeria, United States of America, Bahrain, Brunei Darussalam, Chile, Ethiopia, Fiji, Gabon, Hong Kong, Japan, Congo, South Korea, Cuba, Kuwait, Macao, Malaysia, Maldives, Niger, Oman, Panama, Papua New Guinea, Philippines, Qatar, Republic of Palau, China, Saudi Arabia, Singapore, Solomon Island, Taiwan, Tajikistan, Thailand, Timor Leste, Turkey, Uganda, United Arab Emirates, Jordan, Zambia. From the 40 countries listed as migrant workers targets from Lampung, there are countries with the most migration destinations, namely; Taiwan, Japan, South Korea, Malaysia, Hong Kong, Singapore. In addition to the geographical proximity to Indonesia, there are special reasons that cause migrant workers from Lampung to choose these countries as the main target for job opportunities. The following paragraphs state the main reasons.

The selection of Malaysia as the target of migration with the aim of working is due to: (1) common language and culture with migrant workers; (2) higher wages when compared to working in Indonesia; (3) seeking first experience as migrant workers; (4) the difficulty of finding work in Indonesia; (5) and geographical proximity to Indonesia (source: results of interviews with 4 migrant workers informants in Malaysia, end of July 2020). Judging from the factors causing the migration of migrant workers to Malaysia, it can be said that the main driving factors or push factors are the difficulty of finding work in Indonesia and the low wages of workers in Indonesia. Meanwhile, the pull factors that caused migrant workers to choose Malaysia were the similarity of language and culture with migrant workers, greater job opportunities, and wages are much higher than if they work in Indonesia.

The selection of Taiwan as a place to work for migrant workers from Lampung was based on several considerations, namely: (1) have more job opportunities than in Indonesia; (2) there are greater 
job opportunities; (3) migrant workers can still work without having to master the Taiwanese language; (4) a stable and guaranteed level of state security; (5) individual culture in Taiwan which is more orderly, there is an attitude of respect for one another (respect for immigrants despite their religious differences), and the level of security in Taiwan which tends to be stable; (6) the wages earned are higher than in Indonesia; (7) the right to adequate rest; (8) uncomplicated work requirements; and (9) opportunity to seek new knowledge and gain insight from different cultures (source: interview with 3 migrant workers in Taiwan, end of July 2020). This data shows that although the push factors for migrant workers in Taiwan are almost the same as migrant workers in Malaysia, the pull factors are more varied, including stable and guaranteed security, the society is orderly, the opportunity to learn new cultures and gain insight, the work requirements are not complicated and do not have to go home to extend the work permit, the right to adequate rest, respect for the individual rights of migrant workers and mutual respect from the local community, high wages, still can work even though they can't speak Taiwanese, and there are more and varied job opportunities.

The selection of Japan as the target country for migrant workers from Lampung was based on several factors, namely: (1) attractive culture in Japan, advanced technology; (2) already have basic Japanese language skills; (3) can meet the needs of an increasing number of families; (4) beautiful and interesting scenery that is different from Indonesia; (5) Japan has a strict level of security and high discipline; (6) higher wages in Japan (source: interview with 3 migrant workers from Lampung, late July 2020). This data shows that the pull factors of migrant workers from Lampung who work in Japan include things that are similar to factors in Taiwan, namely community discipline and order, high wages, beautiful scenery, and a new culture that expands knowledge and insight.

The following paragraphs will describe the factors that led to the selection of Hong Kong as the destination country for migrant workers. Migrant workers from Lampung chose Hong Kong as a place to work for the following reasons: (1) a higher currency value than Indonesia, (2) higher wages compared to working in Indonesia and several other countries; (3) high tolerance value; (4) having more holidays than other countries can help relieve stress and be used for sightseeing; ; (5) the existence of higher wages that can be used to build a house and prosper their extended family; and (6) good working environment (source: interview with 2 migrant workers from Lampung, late July 2020).

South Korea has become the target of working abroad for migrant workers from Lampung for several reasons: (1) this country is a country that is considered relatively safe for migrant workers; (2) consideration of the fast handling by the South Korean government if there is a problem with migrant workers; (3) migrant workers thinks that working in Indonesia is difficult; and (4) the wages he gets are greater than if he works in Indonesia or in several other countries, so that it can be used as business capital that will create jobs for the people in his hometown (source: interview with a migrant workers in South Korea, end of July 2020 ).

Another country that is quite a favorite choice for migrant workers from Lampung is Singapore. This country is the main target for migrant workers from Lampung because: (1) migrant workers are considered as part of the family and not considered as workers in general so that migrant workers feel happy to work; (2) Singaporeans are considered friendly; (3) have a cognate language; (4) wages earned while working in Indonesia are low and facilities are minimal; (5) good and complete working facilities; (6) periodic facilities, namely medical check-ups every three months which is a program of the Singapore government; and (7) can learn to speak English well through the learning process in the family where they work, so that migrant workers can pass these English skills to their children in Indonesia (source: interview with a migrant workers in Singapore, end of July 2020).

Regarding the selected countries for migrant workers from Lampung, there are several countries other than destination countries that are most in demand by migrant workers from Lampung. These other countries include Gabon, Nigeria, Zambia, and several countries in the Middle East. For the countries of Gabon, Nigeria, and Zambia, migrant workers consideration for working there is the availability of employment in the mining sector. While the consideration of choosing countries in the Middle East is the motive to be able to perform the pilgrimage or religious factors that are easier due to their close geographical location. The Maldives became the target of migrant workers from Lampung to work in the hotel and tourism sector. For the Maldives itself, Indonesian migrant workers get more benefits because this migrant work is middle and upper class, and for wages during the Covid-19 pandemic, workers who were sent home still received wages and there were no layoffs (source: FGD at BP2MI July 23, 2020).

Returning to the theoretical approach of this research, the various factors that encourage migrant workers from Lampung to choose the target country, this research data shows that there are several contributing factors. The first is the economic factor, namely wider job opportunities than employment opportunities in Indonesia, wages that are higher than the wages that workers will get when working in Indonesia. The second factor is the cultural factor 
which includes the similarity of language and culture between migrant workers and the community at work, the opportunity to learn the language and culture of another country, the opportunity to broaden the horizons of life, the friendliness of the people in the workplace, the appreciation of the local community towards migrant workers, the opportunity to see the beauty of other countries. The next factor is the security factor which includes physical security for migrant workers, local community order, guarantee of local state protection if migrant workersencounters problems; guarantee of the ease of extending work permits without the need to return to Indonesia, guarantee of the security of the continuity of work and income even in a pandemic situation and having to return to Indonesia. Other factors that cause migrant workers to choose a destination country are environmental factors (cleanliness and beauty of the country where they work), medical check-up facilities, job opportunities for migrant workers with middle to upper class skills (mining, restaurant and hotel sectors)

\section{B. Support for Migrant Workers}

To support migrant workers interests for obtaining employment opportunities abroad, this research also tries to reveal the things that are done by various institutions, especially state institutions (Manpower Office and other ministries) and state auxiliary agencies (especially BP2MI), both for providing policy support and other matters. Data from the Lampung Provincial Manpower Office (FGD at the Lampung Provincial Manpower Office, June 12, 2020) shows that the Manpower Office supports migrant workers from Lampung by developing a framework for supporting administrative processes that are relatively easier. In the FGD data obtained that the government, in particular the Manpower Office, provides administrative processing support (correspondence), training through the Job Training Center (or UPT Balai Latihan Kerja) owned by the Provincial Government, facilitate the departure and return of Indonesian migrant workers.

Data from BP2MI (FGD at BP2MI Lampung, July $23,2020)$ shows that the state and related institutions provide support in the form of the process of sending migrant workers abroad through collaboration: (1) Government to Government ( $G$ to $G$ ), namely the government of the sending country and the government of the receiving country cooperate for the existence of migrant workers from Indonesia. The $G$ to $G$ began with a Memorandum of Understanding (MoU) to implement migrant workers placement. In Indonesia, the $G$ to $G$ has been carried out between Indonesia - South Korea, which includes 14 sectors that are currently running in the fisheries and manufacturing sectors and Indonesia - Japan which cooperates for migrants in the labor of medical personnel (senior nurses and doctor assistant nurses). However, $G$ to $G$ only applies to citizens who have a diploma and a bachelor's level of education; (2) Government to Private ( $G$ to $P$ ), namely the government in cooperation with private institutions in the agreed placement country. G to P has been carried out in several countries, namely in Kuwait where Indonesian migrant workers are needed to become drivers of pilgrims and tours. Unfortunately, Kuwait's $\mathrm{G}$ to $\mathrm{P}$ was stopped due to low wages and obstacles in the form of having to master English. Then in Australia, Indonesian migrant workers are needed to become butchers (meat cutters). Unfortunately, this has also stopped because Indonesian migrant workers need a certificate to work as a butcher, while in Indonesia only welders have certificate permits. Furthermore, there is a $\mathrm{G}$ to $\mathrm{P}$ with Canada being built for Indonesian migrant workers to become nurses; (3) Private to Private ( $\mathrm{P}$ to $\mathrm{P}$ ), namely the private sector in Indonesia that cooperates with the private sector in the country of placement, and agrees to carry out the placement process. The private sector in Indonesia must also have permission from the Ministry of Manpower to carry out such cooperation. Several countries such as Taiwan, Hong Kong, Malaysia, Singapore, Brunei Darussalam, and the Middle East, before finally being suspended (moratorium) in 2015 due to the many problems of migrant workers, are countries that carry out $\mathrm{P}$ to $\mathrm{P}$. In $\mathrm{P}$ to $\mathrm{P}$, migrant workers tend to be in the lower-middle sector such as garden workers, domestic workers, and drivers; (4) For the Company's Own Interest (Untuk Kepentingan Perusahaan Sendiri or UKPS/Intercorporate Transport), namely an Indonesian-owned company that has branches in other countries which can become the country of placement. Then, with the existence of this branch, migrant workers are sent to assist the production process at the branch company. In Indonesia, there are PT Indofood Makmur which has branches in Malaysia and PT Semen Nusantara which has branches in Vietnam. Migrant workers in this field can only go through the UKPS door; (5) Independent, namely individuals who have high skills and apply for work independently without the assistance of a migrant worker agency. This individual can go to any country provided that he has been accepted in the destination country and not in a sole proprietorship. However, these migrant workers must have a minimum position as a manager or a middle to upper high skill position. In Solomon Island, Indonesian migrant workers who pass through the independent gate, usually working with the positions as mechanical technician or engineer, machine operator, and others.

In addition, there are several other schemes to assist migrant workers through: (1) Special Placement Program to Taiwan (SP2T), namely Taiwan in collaboration with the Indonesian government for the placement process. This cannot be called $G$ to $G$, because Taiwan is still part of China (one China policy). So, to become an Indonesian migrant worker, you can go through SP2T and P to P; (2) Specified 
Skilled Worker (SSW), the Japanese Parliament, which is a program for those who have had an internship and have a desire to return to work or for prospective workers who want to work outside of the workforce as nursing and medical assistant nurses; (3) One Channel Placement System (SistemPenempatan Satu Kanal or SPSK), was formed due to the impact of the Middle East moratorium in 2015. The Ministry of Manpower issued this SPSK with the aim that, it does not allow prospective migrant workers to be sent directly to the Middle East.

The state provides support for migrant workers in other forms, namely: (1) For migrant workers who do not have fees, it can be facilitated by mandatory People's Business Credit (Kredit Usaha Rakyat or KUR) at the Bank (12\% business credit) which can then be paid by the process of deducting the wages of migrant workers; (2) Consular protection for Indonesian migrant workers provides legal assistance, namely in the example of the case of one of the Indonesian migrant workers who was in Australia due to the migrant worker's employer forcing the migrant worker to also move from the Middle East to Australia, with the position of the migrant worker's document being detained, then this migrant worker makes a report to the consular post. So that the consular officer helps to provide such a passport as a single journey and legal assistance on reporting cases of exploitation by the migrant worker's employer by providing lawyers free of charge, until the case is completed: (3) Diplomatic protection of Indonesian migrant workers, namely facilitating legal protection for migrant workers in the country of placement. For example, in the case of Daryati, a domestic helper who is an Indonesian migrant worker from Lampung Province who was threatened with the death penalty for killing her employer. Indonesia protected and facilitated Daryati to meet her family and paid for family accommodation to go to Daryati's country of placement; (4) training that can provide the skills and knowledge for migrant workers before leaving for the destination country. The training created an understanding of the dangers of radicalism; applicable law in the country of placement; customs adopted by the local country; and the dangers of drugs. Thus, Indonesian migrant workers can understand their country of placement better.

The government's support opens job opportunities for migrant workers abroad with the $G$ to $G, G$ to $P$ cooperation scheme, as well as encouraging other schemes which ultimately affect the employment opportunities for migrant workers abroad. Data from the Lampung Provincial Manpower Office shows that there are several main work sectors that currently become the work sectors of migrant workers abroad, including plantations and domestic workers. However, from the data at the beginning of this paper, it can be seen that this support has not significantly increased the number of workers in the formal sector.
The constraints faced include the lack of skills and mastery of foreign languages. The majority of workers from Lampung work in the informal sector, especially in the field of domestic workers. The number of migrant workers from Lampung who work in the non-formal sector causes the salary they get can't compete when compared to the salary they get in the formal sector.

\section{CONCLUSION}

This study aims to produce a study of the distribution pattern and factors that influence the selection of destination countries for Indonesian migrant workers from Lampung. In this study, several theories are used as a reference for the analysis of the phenomenon under study. The most important of these theories is the theory of migration which is interpreted as the movement of people across regional boundaries to other regional boundaries within a certain period of time [12]. The migration can be permanent or non-permanent; internal and international; settled or not settled in the destination area. Migrant workers make decisions to migrate because of their networks of personal relationships, existing experiences, and beliefs [13]; while according to Everett $\mathrm{S}$. Lee, there are 4 factors that affect migration flows, namely factors in the area of origin, factors at the destination, intermediate barriers, and individual factors [12]. Everet Lee (1966) states that there are push and pull factors for a person to migrate between countries [14]. The driving factors from the country of origin of migrant workers are the consideration of low salaries, limited employment opportunities and low social access of people in the country of origin. While the pull factors in the country of placement are competitive salaries, low unemployment and the tendency of someone to leave their home country.

Neoclassical economy theory [15], especially the macro approach, assumes that the main cause of migration is the difference in wages between sending and receiving countries and labor market mechanisms that facilitate the flow of migrant workers. In addition, policies between sending and receiving countries also greatly affect the size of labor migration [15]. Another migration theory is the chain migration theory in the form of the presence of family or friends who are already in the destination country. Mabogunje (1970) and Kritz\& Zlotnik (1992) state that migration decision making is not only due to push and pull factors but also cultural factors, social systems, access to migration and psychological factors of migrating actors [18],[19]. This theory complements the theory of Everett S. Lee [12]. According to Mabogunje (1970) and Kritz\& Zlotnik (1992), psychological factors that influence individual migration decisions are determined by the characteristics of migrant actors, namely age or education [18], [19]. Likewise, poor migration access in destination areas makes migration actors choose destinations where migration access is easy to obtain [1]. 
The research results showed that the most popular destination countries among migrant workers from Lampung are Taiwan, followed by Hong Kong, Malaysia, Singapore, and Brunei Darussalam. These countries are the destination of the majority of migrant workers who work in the informal sector as domestic workers. Other countries are also destinations for migrant workers from Lampung, especially migrant workers with higher skills or work skills. They work in several countries in Africa, Europe, and Latin America. The main sectors of this type of migrant workers are the hotel and restaurant sector, as well as mining. Some migrant workers also work in the Middle East as drivers.

The results of the following research showed that the most popular destination countries among migrant workers from Lampung are Taiwan, followed by Hong Kong, Malaysia, Singapore, and Brunei Darussalam. The main factors that drove migrant workers to work abroad are limited access and employment opportunities in the country and higher salaries abroad. Socio-cultural factors that influenced the selection of destination countries for immigrant workers from Lampung are the similarity of language and culture that are still allied, the presence of friends or relatives who have previously worked abroad (chain migration), and the friendliness and respect of the local population towards migrant workers. Security factors that influenced the decision to select the destination country include social security and good health in the workplace, local government services that are fast and reliable, as well as ensuring security and order. Meanwhile, other factors that influenced the selection of the destination country are uncomplicated work requirements and migrant worker's interest in technological advances in the destination country.

\section{REFERENCES}

[1] R. T. Utami \& Sukamdi. Pengambilan Keputusan Bermigrasi Pekerja Migran Perempuan (Kasus di Desa Jangkaran, Kecamatan Temon Kabupaten Kulon Progo), Research Report. 2012.

[2] Katadata. Malaysia is Still the Main Destination for Indonesian Migrant workers. 9 April 2019 (https://databoks.katadata.co.id/datapublish/2019/04/09/malay sia-masih-menjadi-purpose-utama-para-energi -kerjaindonesia), accessed on February 8, 2020

[3] Radar Lampung. TKI Asal Mesuji Terus Meningkat, Dua Negara Jadi Favorit. January 2020, available: https://radarlampung.co.id/tki-asal-mesuji-terus-meningkatdua-negara-jadi-favorit/, accessed: 28 September 2021.

[4] Sihombing, H., Yaakob, MH, Safarudin, M. The business perspectives strategy towards the TKI (Indonesian Migrant workers) market. Journal of Indonesian Economy and Business. Volume 26 number 1. 2011. 64-89.

[5] T. Loganathan. D. Rui., C.W. Ng., N.S. Pocock. Breaking down the barriers: Understanding migrant workers' access to healthcare in Malaysia. PLoS one. 2019. 14(7), e0218669. https://doi.org/ 10.1371/journal.pone.0218669

[6] M.Y. Madrah., Suharko. Migrant workers as Cultural Intermediaries. KOMUNITAS: International Journal of Indonesian Society and Culture. 11(1). 2019. pp. 129-140
[7] J. Sayono., I.W.P. Utami., L. Ayundari. Migrant workers and Socio-economic Changes. Masyarakat, Kebudayaan dan Politik, 31(2), 2018. 176-189.

[8] F. Wright, \& S. Clibborn. Migrant labour and low-quality work: A persistent relationship. Journal of Industrial Relations, 61(2), 2019. 157-175.

[9] Bretones, FD, Jain, A. Leka, S., Garcia-Lopez, PA. Psychosocial working conditions and well-being of migrant workers in Spain. International Journal of Environmental Research and Public Health. Volume 17 issue 7. April 2020 Labormigran.or.id, Getting to Know Sub-Contractor Migrant workers, $\quad 10$ December 2018, (https://buruhmigran.or.id/2018/12/10/mengenal-pekerjamigran-sub-contractor/), accessed on February 8, 2020

[10] Rustage, K., Nellums, LB, McAlpine, A., Pocock, N. Occupational health outcomes among international migrant workers: a systematic review and meta-analysis. The Lancet Global Health. Volume 7 issue 71 July 2019.

[11] International Organization for Migration, 2010, Labour Migration from Indonesia, Jakarta: IOM. Available: https://www.iom.int/sites/g/files/tmzbdl486/files/jahia/webda v/shared/shared/mainsite/published_docs/Final-LM-ReportEnglish.pdf

[12] Lee, Everett S. 2000. Theory of Migration Translated Series No.3, Translated By Hans Daeng, Revisited By Mantra. Yogyakarta: PSKK UGM

[13] IDA Bagus Mantra Keban, Yeremias T. Kasto, 1999 , Mobilitas Tenaga Kerja Indoneisa ke Malaysia: Studi Kasus Flores Timur Tengah, Pulau Bawean, Yogyakarta: Pusat Penelitian Kependudukan, Universitas Gadja Mada. Available: https://opac.perpusnas.go.id/DetailOpac.aspx?id=279127

[14] Lee, Everett S. 1966. A Theory of Migration. Demographics, Vol. 3, No. 1. (1966), pp. 47-57. URL: http://links.jstor.org/sici?sici=0070$3370 \% 281966 \% 293 \% 3 \mathrm{~A} 1 \% 3 \mathrm{C} 47 \% 3 \mathrm{AATOM} \% 3 \mathrm{E} 2.0 . \mathrm{CO} \% 3$ B2-B

[15] Massey, Douglas S., Arango, J., Hugo, G., Kouaouci, A., Pellegrino, A., Taylor, J. Edward. 2011. Theories of International Migration: A Review and Appraisal. Population and Development Review, Vol. 19, No. 3 (Sep., 1993), pp. 431-466. Stable URL: http://www.jstor.org/stable/2938462

[16] International Organization for Migration, LABOR MIGRATION FROM INDONESIA: Overview of Indonesian Labor Migration in Several Destination Countries in Asia and Middle East, (https://www.iom.int/jahia/webdav/shared/shared/mainsite/pu blished_docs/Final-LM-Report-Bahasa-Indonesia.pdf)

[17] Susilo, S.. 2016. Several factors determine TKI in choosing a destination country as a place to work. Journal of Geography Education: Study of Theory and Practice in the Field of Education and Geography. Year 21 number 2, June 2016

[18] Mabogunje, 1970. "System Approach to a Theory of RuralUrban Migration," in Geographical Analysis, 2, 431-466, 70.www.journal.unair.ac.id//pdf.

[19] Kritz, M. and H. Zlotnik. 1992. "Global Interactions: Migration Systems, Processes, and Policies". In International Migraton Systems: A Global Approach. Oxford: Clarendon Press. Lambost, Lampung Has 21,472 Indonesian Migrant workers, 2 February 2020, https://www.lampost.co/beritalampung-miliki-21-472-pekerja-migran-indonesia.html, accessed on 8 February 2020

[20] Sugiyono. 2010. Metode Penelitian Pendidikan Pendekatan Kuantitatif, Kualitatif, dan R\&D. Bandung: Alfabeta. pp.245.

[21] Lexy. J. Moleong. 2000. Metodologi Penelitian Kualitatif. Bandung: PT Remaja Rosdakarya. Pp.207. 